\title{
The problem of giving opinion by psychology expert in family and caretaking cases
}

\author{
Problematyka sporządzania opinii przez biegłego psychologa w sprawach \\ rodzinnych i opiekuńczych
}

\author{
Aleksandra Iwanicka ${ }^{1}$ ABDEF, https://orcid.org/0000-0002-8603-4732 \\ Joanna Iwanicka² ABDEF, https://orcid.org/0000-0002-1891-5351 \\ Anna Urbańska ${ }^{1}$ DEF, https://orcid.org/0000-0001-8190-8173
}

${ }^{1}$ II Department of Psychiatry and Psychiatry Rehabilitation, Medical University of Lublin

${ }^{2}$ Adw. Katarzyna Taramas-Mazurkiewicz Lawyer's Office

\begin{abstract}
The aim of the article is to point out to the specificity and difficulties an expert psychologist faces while producing a court expertise in family and guardianship cases. Such a diagnosis is prepared at the request of a family court. The questions asked by the court in family and guardianship cases determine the range and aim of diagnosis including the type of examined case. Having considered the court's questions, a psychologist formulates hypotheses and operationalizes variables. This article will present the main areas of problems which arise while developing opinions in family and guardianship cases. The two main issues will be discussed: the range of an expert psychologist's competences in the light of the court's expectations frequently exceeding an expert's capabilities and the impact of the choice of research methods on the quality of an opinion issued to obtain the final ruling in the court case.
\end{abstract}

Keywords: Court expertise, psychologist's competences, research methods

\section{Streszczenie}

Celem artykułu jest wskazanie specyfiki i trudności, z którymi mierzy się biegły psycholog przygotowując ekspertyzę sądową w sprawach rodzinnych i opiekuńczych. Diagnoza taka, jest wykonywana na zlecenie sądu rodzinnego. W sprawach rodzinnych i opiekuńczych pytania sądu do biegłego psychologa wyznaczają zakres i cel diagnozy uwzględniając rodzaj rozpoznawanej sprawy. Po zapoznaniu się z pytaniami sądu psycholog przekształca je na hipotezy i operacjonalizuje zmienne. W niniejszym artykule zostaną przedstawione główne obszary problematyki opiniodawczej w sprawach rodzinnych i opiekuńczych. Omówione zostaną dwa podstawowe zagadnienia: zakres kompetencji biegłego psychologa w świetle często wykraczających poza możliwości biegłego oczekiwań sądu oraz wpływ doboru metod badawczych, na jakość sporządzanej opinii dla finalnego rozstrzygnięcia sprawy sądowej.

Słowa kluczowe: ekspertyza sądowa, kompetencje psychologa, metody badawcze

\section{Introduction}

Issuing of court opinions in family and guardianship cases constitutes a unique area of the expert activity of psychologists [1]. This results from numerous conditions such as the most recent changes into the legislation concerning family and guardianship matters as well as the degree of complexity of a problem being a subject of an opinion. The above mentioned aspects raise a number of doubts and ambiguities relating to, for example, ethical dimension of a psychologist's profession who, as a courtappointed expert, is forced to combine frequently diverging expectations of the law and psychology $[2,3]$.

The role of an expert's opinion in family and care cases

A court-appointed expert is the assisting authority of the justice system [4]. Pursuant to article 278 § 1 
in connection with article 236 of the act of November 11, 1964 of the Code of Civil Procedure, the court, by way of reasoned order, appoints an expert in a case when special knowledge is necessary to give a final ruling [5]. It encompasses information from individual disciplines such as science, technology, art, crafts and all other skills going beyond the average level of knowledge of people who are not specialists in a given discipline [6].

In the light of the settled position of the jurisdiction, an expert's task is not to establish the facts of the case but rather to highlight and make the court able to clarify the circumstances from the point of view of the special knowledge possessed by an expert with respect to the collected evidence made available to him or her [7].

While issuing an opinion, an expert should restrict his or her activity in legal proceedings to answering questions that have been asked in the way most adequately corresponding with the facts of the case including potential discussion of possible versions of solutions resulting from the presented documents, but not limiting himself or herself to only one version of evaluation, especially the one that has not been meriti indicated by the court [8].

Issuing opinions in family and care cases constitutes a specific area of psychologists' activity for the needs of the justice system. The aim of psychological diagnosis is frequently to determine the relationships within a family, establishing of emotional bonds between a child and parents or the analysis of their parental and upbringing competences that is essential to make decisions concerning the range of parental authority they have over a child [9]. Family cases, in which exceptionally intimate issues are very frequently discussed and resolved, are without doubt one of the most difficult type of cases examined by the courts. The cooperation between an expert psychologist and the court enables to make the best and the most accurate decisions at the same time eliminating, to a degree that it is of course possible, far-reaching consequences of mistakes in issued rulings [10].

By virtue of the assisting role of an expert, it shall be pointed out that it is a deciding authority that is substantially bound by the obligation of transparency in the process of passing of the information. That is why the court, while issuing a decision on expert witness evidence, shall formulate the evidence thesis in a way that is the most comprehensive and clear for an expert [8].

In its evidence decision, the court is obliged to indicate the range and direction of an expert's opinion, as well as to inform of the facts that have already been established but still need to be clarified by an expert. Moreover, the court shall quote all circumstances that raise doubts and therefore need to be addressed or accurately interpreted by an expert [4]. In family and care cases, the questions concerning the range and aim of diagnosis that the court asks an expert involve a type of case that is being considered. For instance, in divorce cases, the aim of psychological examination is to provide evidence that helps to establish if a potential decision on the divorce will not infringe "child's best interest" (pursuant to article $56 \S 2$ of the Act of 25 February 1964 to promulgate the Family and Guardianship Code) [11]. Is one of the two circumstances which exclude admissibility of the decision on divorce and which parent shall be entrusted the permanent care over a child.

The court's evidence thesis contains the questions concerning the counter-indications for divorce due to a child's best interest, indication of a carer who is able to guarantee and ensure better educational conditions, assessment of educational competences of a parent who wants to look after a child, indications connected with the form and range of care provided by another parent, instructions concerning emotional bond between parents and a child and their predicted shape in the future, as well as so-called specific questions, for example the ones regarding a potential need of a child's or family's psychological therapy [9].

\section{The limits of an expert's competences}

In the light of the above presented regulations, the actual scope of an expert psychologist's competences remains an important issue. In every situation when an expert undertakes professional activities, he or she must possess extensive and thorough psychological knowledge of a child's development, family and interpersonal communication [12]. A psychologist's expertise shall be also supplemented with the knowledge of the family and guardianship law and court procedures. A psychologist is responsible for a methodological level of an opinion, the application of relevant and proven diagnostic methods and interpreting of the obtained diagnostic material exclusively. An accurately, methodologically produced opinion is useful in the court procedure only if it is logical, answers the court's questions and has been formulated in a comprehensive way [12].

The above presented range of an expert psychologist's competences fosters to take the floor in the discussion on formulating of evidence theses by the court. As may be concluded from recently conducted studies, the level of detail in questions the court asks experts is significant. There is no reason to expect that the court will use the language of the discipline represented by an expert. As long as the court's expectations are clear and adjusted to an expert psychologist's competences, he or she will be able to reformulate them into a specific psychological problem $[12,13]$. The fact that the court uses affirmative, 
interrogative or imperative sentences while formulating an evidence thesis is of no significance. What is essential, however, is the fact that the court separates the areas indicated in the individual theses. Otherwise, an expert who formulates conclusions is forced to repeat the same information in subsequent points or give joint answers to some theses which contributes to the fact that his or her conclusions become less clear for opinion recipients [13].

The problems with formulating of evidence theses also concern the degree of their detail. If it is too extensive, an expert finds it difficult to formulate conclusions in a permanent and clear way. Referring to details may also considerably narrow the range of opinion and omit significant issues [14]. The most serious difficulty pose provision theses which partially or completely exceed the competences of an expert psychologist. The court cannot ask an expert about concrete solutions, for example: which parent shall be conferred with parental authority or shall a mother or a father be deprived of parental authority. An expert's meeting of such an expectation would result in obvious interference with the powers of the courts.

\section{Methods used in psychological diagnosis}

An expert decides on the choice of the diagnostic tools and is responsible for them. He or she pays attention to the fact that research instruments meet the diagnostic requirements to a large extent. Moreover, they are selected in such a way that they are able to verify a set out thesis at the same time involving abilities of examined people and their attitude towards the examination. A psychologist's task is to establish if the current psychological knowledge (theory and practice) will allow to implement the aim of examination formulated in the court decision [15].

While selecting a diagnostic method, a psychologist shall take into consideration his or her own experience in using of a given tool. Every psychologist's ethical obligation is to continually improve in using of diagnostic methods and trace new research trends appearing on the market [15]. It shall be emphasized that a new method may be used only if we already have competences in examination and interpretation of the obtained results. The key problem is also a good knowledge of a psychological theory a given test refers to [15].

Basic requirements concerning the use of a specific diagnostic technique while diagnosing for the court purposes must have firm scientific grounds, meet psychometric conditions (accuracy, reliability, objectivity, standardization, normalization). The applied diagnostic tools must be adopted to the Polish conditions, possess current normalization (that is, the newest of all available ones) and be used in complete accordance with the instructions $[15,16]$.

While selecting diagnostic tools for a specific problem, we adopt the principle that there cannot exist one pattern of the applied research methods. The similarity of questions asked by the court or situations in which the examined families are, very frequently makes an expert use the same research scheme and the same set of methods. This may lead to omissions in substantial and important facts in functioning of a given family. The repetitive use of learned research schemes frequently prevents an adequate choice of the best set of tests for actual traits of examined people [15, 17].

As an example, it would be useful to refer to the question frequently set by the court concerning the educational competences of parents, which makes an expert determine in what relationships and patterns of behavior towards a child they are expressed [18,19]. A psychologist, in his or her evaluation, uses all available sources of information and a deepened interview with parents bearing in mind the factors which may impair accuracy and reliability of thesis, for example, a parent's self-presentation may be considerably divergent from his or her actual behavior and beliefs [19].

In practice, the diagnosis of parents' educational competences will be limited to the examination of parental educational attitudes and characteristic of the educational style presented by parents. Research tools used to examine parental attitudes available in Poland are self-descriptive and declaratory, therefore they frequently provide merely some image of parents and the way in which they should represent themselves in order to obtain the right of care over a child [14]. The data from questionnaires should be carefully and in detail confronted with the information obtained from the interview, the attitude towards the examination and cohesion of verbal declarations with behavior [15].

The use of projection methods in examinations conducted for the needs of the court remains a problematic issue. It raises numerous doubts because a psychologist who chooses a projection method has to know its diagnostic and psychometric value. In psychological practice, in addition to the techniques with diagnostic values such as Rotter Incomplete Sentence Blank, there are methods of questionable value such as Koch's tree test or Szondi test [20]. The Roschach inkblot test also raises a lot of controversy. The full version of this test and possible interpretations are available on the Internet what results in actual accuracy and reliability of this method.

Lilienfield, Wood and Garb conducted a quantitative analysis of accuracy of projection techniques in detection of sexual violence against children. The results presented by them prove the lack of sufficient evidence of their efficiency in diagnosing of these types of violence. The results 
also indicate that currently there are a lot of unjustifiable views on projection techniques that lack any scientific proof [21]. Another issue also raising a lot of doubts is a subjective way of interpretation of projection tools. Even the essential knowledge of theory underlying the tools and pattern of variables which are examined does not protect a diagnostician from the influence of their own beliefs on the interpretation of the obtained material [22].

\section{Conclusions}

1. An opinion produced by an expert presented to the court is the key evidence on which the final ruling is based, especially in the area of the family and guardianship law. The opinion of an expert psychologist explains and clarifies the circumstances, the comprehension of which requires a psychologist's knowledge and experience.
2. Psychological diagnostics of family relationships is a difficult and complex task. Issuing of the court opinions in family and care cases requires outstanding professional competences.

3. Difficulties, an expert faces while producing opinions for the court involving family and guardianship cases, points out to how many factors determine the final conclusions presented to the court.

4. The courts are hardly ever aware of the diagnostic process and circumstances affecting its course such as an opportunity of various choice of research methods by an expert psychologist.

5. The awareness of the stages of developing an opinion that an expert has to go through and difficulties he or she faces answering too general or too detailed questions is of the key importance when it comes to the assessment of the value of evidence in the case.

\section{Wstęp}

Opiniowanie sądowe $\mathrm{w}$ sprawach rodzinnych i opiekuńczych to szczególny obszar eksperckiej aktywności psychologów [1]. Wynika to z wielu uwarunkowań, chociażby $\mathrm{z}$ najnowszych zmian $\mathrm{w}$ przepisach prawnych dotyczących kwestii rodzinnych i opiekuńczych, poziomu złożoności, skomplikowania, problematyki będącej przedmiotem opinii. Powyższe aspekty budzą szereg wątpliwości i niejasności odnoszących się na przykład do etycznego wymiaru pracy psychologa, który jako biegły sądowy jest zmuszony łączyć ze sobą często rozbieżne oczekiwania prawa i psychologii $[2,3]$.

\section{Rola opinii biegłego w sprawach rodzinnych i opiekuńczych}

Biegły jest organem pomocniczym wymiaru sprawiedliwości [4]. Zgodnie z art. $278 \S 1$ w zw. z art. 236 ustawy z dnia 17.11.1964 r. Kodeksu postępowania cywilnego, biegłego powołuje $\mathrm{w}$ drodze postanowienia sąd w przypadku, gdy do wydania orzeczenia w sprawie niezbędne jest posiadanie wiadomości specjalnych [5]. Obejmują one wiedzę z zakresu poszczególnych gałęzi nauki, techniki, sztuki, rzemiosła oraz wszelkich innych umiejętności, wykraczającą poza przeciętny poziom wiedzy osób nie będących specjalistami w danej dziedzinie [6].

W świetle utrwalonego stanowiska judykatury zadaniem biegłego nie jest ustalenie stanu faktycznego sprawy, lecz naświetlenie i umożliwienie wyjaśnienia przez sąd okoliczności z punktu widzenia posiadanych przez biegłego wiadomości specjalnych przy uwzględnieniu zebranego i udostępnionego mu materiału dowodowego [7].

Biegły w wydawanej opinii powinien ograniczyć swoją aktywność procesową do udzielenia odpowiedzi na postawione pytania adekwatnie do stanu faktycznego sprawy, nie wyłączając ewentualnego omówienia możliwych wersji rozwiązań wynikających z przedstawionej dokumentacji, ale nie ograniczając się do tylko jednej wersji oceny, i to wersji niewskazanej przez sąd meriti [8].

Opiniowanie biegłych w sprawach rodzinnych i opiekuńczych stanowi szczególny obszar aktywności psychologów dla potrzeb wymiaru sprawiedliwości. Zazwyczaj celem diagnozy psychologicznej jest określenie relacji w rodzinie, kształtowania więzi emocjonalnych dziecka z rodzicami czy też analiza posiadanych przez nich kompetencji wychowawczych, mająca istotne znaczenie w rozstrzygnięciu o zakresie przysługującej im władzy rodzicielskiej nad dzieckiem [9]. Sprawy rodzinne, w których roztrząsane i rozstrzygane są niejednokrotnie kwestie nader intymne są bez wątpienia jednym z najtrudniejszych w rozpoznaniu rodzajem spraw sądowych. Współpraca sądu z biegłym psychologiem umożliwia podejmowanie najlepszych i najtrafniejszych decyzji, eliminując na ile to możliwe mające daleko idące konsekwencje pomyłki $\mathrm{w}$ wydawanych orzeczeniach [10].

Z uwagi na pomocniczą rolę biegłego względem sądu, należy wskazać, że to na organie orzekającym spoczywa w znacznej mierze obowiązek zapewnienia transparentności $\mathrm{w}$ procesie przekazywania informacji. Z tego względu sąd, wydając postanowienie dowodowe $\mathrm{w}$ zakresie przeprowadzenia dowodu $\mathrm{z}$ opinii biegłego, powinien skonstruować tezę dowodową w sposób jak najbardziej dla niego przejrzysty i zrozumiały [8]. 
Sąd w postanowieniu dowodowym zobligowany jest do wskazania zakresu i kierunku opinii biegłego, a także ewentualnego wskazania już ustalonych faktów, co do których biegły ma złożyć wyjaśnienia. Ponadto sąd powinien przytoczyć okoliczności, które nasuwają wątpliwości i z tego względu wymagają rozstrzygnięcia bądź wskazania kierunku ich interpretacji przez biegłego [4]. W sprawach rodzinnych i opiekuńczych pytania sądu do biegłego psychologa wyznaczające zakres i cel diagnozy uwzględniają rodzaj rozpoznawanej sprawy. Dla przykładu w sprawach rozwodowych badanie psychologiczne ma za zadanie dostarczyć przesłanek do ustalenia czy ewentualne orzeczenie rozwodu nie będzie naruszać "dobra dziecka" (zgodnie z art. 56 § 2 ustawy z dnia 25.02.1964 r. Kodeks rodzinny i opiekuńczy [11]. jest jedną z dwóch przesłanek, których zaistnienie wyłącza dopuszczalność orzeczenia rozwodu) oraz któremu z rodziców powierzyć stałą opiekę nad dzieckiem.

Teza dowodowa sądu zawiera pytania dotyczące przeciwwskazań w udzieleniu rozwodu ze względu na dobro dziecka, wskazania opiekuna, który daje najlepsze gwarancje zapewnienia prawidłowych warunków wychowawczych, ocenę kompetencji wychowawczych rodzica starającego się o opiekę nad dzieckiem, wskazówki, co do formy oraz zakresu opieki ze strony drugiego z rodziców, wskazówki dotyczące więzi uczuciowej dziecka $\mathrm{z}$ rodzicami oraz przewidywanego jej kształtowania w przyszłości, jak również tzw. pytania specyficzne np. dotyczące ewentualnej potrzeby skorzystania z terapii psychologicznej dziecka bądź rodziny [9].

\section{Granice kompetencji biegłego}

W świetle wyżej przedstawionych przepisów ważną kwestią pozostaje rzeczywisty zakres kompetencji biegłego psychologa oraz możliwości, którymi dysponuje. W każdej sytuacji, gdy podejmuje się czynności musi posiadać obszerną wiedze psychologiczną dotyczącą rozwoju dziecka, rodziny, komunikacji interpersonalnej [12]. Wiedza biegłego powinna być uzupełniona o znajomość prawa szczególnie rodzinnego i opiekuńczego a także procedury sądowej. Psycholog jest odpowiedzialny za metodologiczny poziom opinii, stosowanie sprawdzonych metod diagnostycznych i interpretowanie wyłącznie uzyskanego materiału diagnostycznego. Dobrze przygotowana merytorycznie opinia wtedy jest użyteczna w procedurze sądowej, gdy jest logiczna, odpowiada na pytania sądu i została sformułowana językiem zrozumiałym [12].

Wyżej przedstawiony zakres kompetencji biegłego psychologa skłania do zabrania głosu w dyskusji nad formułowaniem tez dowodowych przez sąd. Jak wynika z przeprowadzonych dotychczas badań, szczegółowość pytań zadawanych biegłemu przez sąd jest znaczna. Nie ma powodu oczekiwać od sądu, aby używał języka nauki reprezentowanej przez biegłego, jeśli oczekiwania będą jasne i dostosowane do kompetencji biegłego psychologa, on sam przeformułuje je na konkretny problem psychologiczny $[12,13]$. Nie jest też istotne, czy sąd formułując tezę dowodową użyje trybu pytającego, orzekającego czy rozkazującego. Duże znaczenia ma natomiast, by dbał o rozłączność obszarów wskazywanych w poszczególnych tezach, bo w przeciwnym razie biegły formułując wnioski, jest zmuszony do powtarzania tych samych informacji $\mathrm{w}$ kolejnych punktach, bądź udzielenia łącznych odpowiedzi na niektóre tezy, co staje się mniej czytelne dla odbiorców opinii [13].

Problemy związane z formułowaniem tez dowodowych dotyczą także stopnia ich szczegółowości. Jeśli jest on bardzo duży, utrudnia pracę biegłego i przejrzyste formułowanie wniosków opinii. Odnoszenie się do detali może zawęzić zakres opinii i pominąć istotne kwestie [14]. Najpoważniejszą trudność stanowią tezy postanowienia, które częściowo lub całkowicie wykraczają poza zakres kompetencji biegłego psychologa. Sąd nie może pytać biegłego psychologa o konkretne rozwiązania, np., któremu z rodziców powierzyć władzę rodzicielską?, Czy należy pozbawić matkę, ojca władzy rodzicielskiej? Spełnienie tego oczekiwania pociągałoby za sobą oczywiste ingerowanie biegłych w kompetencje sądu.

\section{Metody stosowane w psychologicznej diagnozie}

Biegły decyduje o wyborze narzędzi diagnostycznych i ponosi za nie odpowiedzialność. Zwraca uwagę, by narzędzia badawcze w wysokim stopniu spełniały wymagania diagnostyczne. Ponadto dobiera je w taki sposób, by były w stanie zweryfikować postawione hipotezy, a zarazem by uwzględniały możliwości osób badanych oraz ich postawę wobec badania. Zadaniem psychologa jest stwierdzenie, czy dostępna wiedza psychologiczna (teoria i praktyka) pozwolą mu zrealizować cel badania sformułowany w postanowieniu sądu [15].

Wybierając metodę diagnostyczną, psycholog powinien uwzględnić swoje doświadczenie w stosowaniu danego narzędzia. Etycznym obowiązkiem każdego psychologa jest stałe doskonalenie się $\mathrm{w}$ posługiwaniu metodami diagnostycznymi, a także śledzenie pojawiających się na rynku nowych metod badawczych [15]. Należy zaznaczyć, że dopiero wtedy możemy wykorzystać nową metodę, gdy mamy kompetencje $\mathrm{w}$ badaniu i interpretacji uzyskanych wyników. Kluczowym problemem jest też dobra znajomość teorii psychologicznej, do której odnosi się dany test [15]. 
Podstawowe wymagania dotyczące posługiwania się określoną techniką diagnostyczną $\mathrm{w}$ diagnozie do celów sądowych muszą mieć solidne podstawy naukowe, spełniać warunki psychometryczne (trafności, rzetelności, obiektywizmu, standaryzacji, normalizacji). Stosowane narzędzia diagnostyczne muszą być adaptowane do warunków polskich, mieć aktualną normalizację, tzn. najnowszą z dostępnych, być stosowane w całości i zgodnie $\mathrm{z}$ instrukcją $[15,16]$.

Dobierając narzędzia diagnostyczne do określonego problemu, przyjmujemy zasadę, że nie może być jednego wzorca stosowanych metod badawczych. Podobieństwo stawianych przez sąd pytań czy sytuacji różnych badanych rodzin często powoduje, że biegły zaczyna posługiwać się tym samym schematem badawczym, wykorzystują ten sam zestaw metod. Może to prowadzić do pomijania istotnych i ważnych dla funkcjonowania danej rodziny elementów. Stosowanie wyuczonych schematów badawczych często uniemożliwia właściwy dobór jak najlepszego zestawu testów do rzeczywistych cech osób badanych $[15,17]$

Dla przykładu warto odnieść się do pytania często stawianego przez sąd dotyczącego kompetencji wychowawczych rodziców, stawia to przed psychologiem konieczność określenia, $w$ jakich relacjach i zachowaniach wobec dziecka są one wyrażane $[18,19]$. Psycholog przy ocenie wykorzystuje wszystkie dostępne źródła informacji, pogłębiony wywiad z rodzicami, pamiętając o czynnikach, które mogą zakłócić rzetelności i trafność stawianej diagnozy np. autoprezentacja rodzica podczas badania może być w znacznym stopniu rozbieżna od jego rzeczywistych zachowań i przekonań [19].

W praktyce diagnoza kompetencji wychowawczych rodziców będzie ograniczać się do zbadania postaw wychowawczych rodziców i charakterystyki stylu wychowawczego prezentowanego przez rodziców. Dostępne w Polsce narzędzia badawcze do badania postaw rodzicielskich są metodami samoopisowymi, deklaratywnymi, które często dostarczają jedynie pewnego wyobrażenia rodziców, jak powinni się prezentować, by uzyskać prawo do opieki nad dzieckiem [14]. Dane pozyskane $\mathrm{z}$ kwestionariuszy należy szczegółowo konfrontować z wiadomościami pochodzącymi z wywiadu, postawą wobec badania, spójnością deklaracji werbalnych z zachowaniem [15].

Problematyczną kwestią pozostaje stosowanie metod projekcyjnych $\mathrm{w}$ badaniach na potrzeby sądu. Budzi to szereg wątpliwości, ponieważ wybierając metodę projekcyjną psycholog musi znać jej wartość diagnostyczną i psychometryczną. W praktyce psychologicznej istnieją obok technik o określonych walorach diagnostycznych takich Test Zdań Niedokończonych Rottera, metody o wątpliwej wartości, np. Test Drzewa Kocha czy Test Schondiego [20].
Również Test Plam Atramentowych Rorschacha wzbudza wiele kontrowersji. Pełną wersje tego testu jest dostępna w Internecie oraz jego przykładowe interpretacje co przekłada się na rzeczywistą trafność i rzetelność metody badawczej.

Lilienfeld, Wood, Garb przeprowadzili analizę ilościową trafności technik projekcyjnych w wykrywaniu przemocy seksualnej wobec dzieci. Przedstawione przez nich wynik świadczą o braku dostatecznych dowodów na to, iż za pomocą tych technik można diagnozować tego typu przypadki przemocy. Wyniki te wskazują, że powszechnie istnieje wiele nieuzasadnionych poglądów dotyczących technik projekcyjnych, nie mających naukowego potwierdzenia [21]. Inną kwestią, która również budzi wątpliwość jest subiektywny sposób interpretacji narzędzi projekcyjnych. Nawet niezbędna znajomość teorii leżącej u podłoża narzędzi oraz charakterystyki zmiennych, które są diagnozowane nie zabezpieczają diagnosty przed wpływem jego własnych przekonań na interpretację uzyskanego materiału [22].

\section{Wnioski}

1. Przedstawiona sądowi opinia biegłego psychologa jest kluczowym dowodem, na którym opiera się finalne rozstrzygnięcie sprawy zwłaszcza z zakresu prawa rodzinnego i opiekuńczego. Opinia biegłego psychologa wyjaśnia i naświetla sądowi okoliczności, których zrozumienie wymaga wiedzy i doświadczenia psychologa.

2. Diagnostyka psychologiczna relacji rodzinnych jest zadaniem niezwykle trudnym i złożonym. Opiniowanie sądowe w sprawach rodzinnych i opiekuńczych wymaga szczególnych kompetencji profesjonalnych.

3. Trudności, które napotka biegły psycholog sporządzając opinie dla sądu na gruncie spraw rodzinnych i opiekuńczych, wskazują jak wiele czynników determinuje zaprezentowane sądowi finalnie wnioski.

4. Sądy bardzo rzadko są świadome procesu diagnostycznego oraz wpływających na jego przebieg okoliczności takich jak możliwość różnorodnego doboru metod badawczych przez biegłego psychologa.

5. Świadomość etapów sporządzania opinii oraz trudności, z którymi mierzy się biegły psycholog, który musi udzielić odpowiedzi na często zbyt ogólnie sformułowane lub bardzo szczegółowe pytania jest istotna przy ocenie jej waloru dowodowego w sprawie. 


\section{Conflict of interest}

The authors have declared no conflict of interest.

\section{References}

1. Pozniak W. Psychologia sądowa - wybrane zagadnienia. W: Sęk H. red. Psychologia kliniczna. Warszawa: Wydawnictwo Naukowe PWN; 2005. s. 287.

2. Budzyńska A. Psycholog w roli biegłego sądowego. Dziecko Krzywdzone, 2007; 4(21): 1-7.

3. Włodarczyk-Madejska J. Opinia biegłego w sprawach cywilnych w świetle badania aktowego. Prawo w działaniu. Sprawy cywilne, 2017; 30: 155-176.

4. Turek J. Dopuszczenie dowodu z opinii biegłego. W: Turka J. red. Rola biegłego we współczesnym procesie. Warszawa: Wydawnictwo Zrzeszenia Prawników Polskich; 2002. s. 7. Dz.U. 1964 nr 43 poz. 296 z późniejszymi zmianami.

5. Postanowienie SN z dnia 27.04.2017 r., syg. akt: III CSK 341/16, LEX nr 2311191.

6. Demendecki T. [w:] Kodeks postępowania cywilnego. Komentarz aktualizowany. Tom I. Art. 1-729, pod. red. A. Jakubeckiego, LEX/ el.2018.

7. Klich A. Dowód z opinii biegłego w postępowaniu cywilnym biegły lekarz. Warszawa: C.H. Beck, 2016.

8. Toeplitz - Winiewska M. Opieka nad dziećmi - standardy opiniowania psychologicznego w sprawach rozwodowych. Psychologia Wychowawcza. 2014; (5): 180.

9. Kasprzyk P. Udział biegłego w sprawach rodzinnych. W: Turka J. red. Rola biegłego we współczesnym procesie. Warszawa: Wydawnictwo Zrzeszenia Prawników Polskich; 2002. s. 80. Dz. U. $1964 \mathrm{nr} 9$ poz. 59 z późniejszymi zmianami.

10. Czeredecka A. Kompetencje biegłego psychologa w odniesieniu do spraw rodzinnych i opiekuńczych. W: Czeredecka A. red. Standardy opiniowania psychologicznego w sprawach rodzinnych i opiekuńczych. Kraków: Wydawnictwo Instytutu Ekspertyz Sądowych; 2016. s. 33 - 48.

11. Czeredecka A. Propozycja standardów opiniowania w sprawach rodzinnych i opiekuńczych; 2016 http://www.wotptp.waw.pl/ wp-content/uploads/2016/03/2016-Standardy-opiniowaniapsychologicznego_sprawy_rodzinne-iopieku\%C5\%84cze_26lutego.pdf (dostęp: 28.07.2018).

12. Strózik I. Podstawowe zasady sporządzania przez biegłych opinii w sprawach rodzinnych W: Czeredecka A. red. Standardy opiniowania psychologicznego w sprawach rodzinnych i opiekuńczych. Kraków: Instytut Ekspertyz Sądowych; 2016. s. 14.

13. Tolepiz-Wiśniewska M. Standardy doboru metod diagnostycznych do problemu i osób badanych. W: Czeredecka A. red. Standardy opiniowania psychologicznego w sprawach rodzinnych i opiekuńczych. Kraków: Instytut Ekspertyz Sądowych; 2016. s. 193-211.

14. Czeredecka A. Kryteria oceny dowodu z opinii psychologicznej w sprawach rodzinnych i opiekuńczych. W: Paluchowski J, Filipiak M, Zalewski B, Tarnowska M. red. Standardy diagnozy psychologicznej. Warszawa: Pracownia Testów Psychologicznych PTP; 2015. s.200223.

15. Bodanko Anatol. Czynności biegłego sądowego z zakresu psychologii jako przykład praktycznego zastosowania metody studium przypadku. Nauczyciel i Szkoła, 2012: 2(52): 185-191.

16. Oleszewska A, Zawadzka A. Rozwodowe trzęsienie ziemi. Jak zadbać o dziecko?. Dziecko krzywdzone. Teoria, badania, praktyka, 2008; 7(4): 120-128.

17. Budzyńska A. Wysłuchanie dziecka w postępowaniu cywilnym - perspektywa psychologiczna. Dziecko krzywdzone. Teoria, badania, praktyka, 2015; 14(4): 32-54.

18. Paluchowski WJ, Stęplewska - Żakowicz K. Wiarygodność technik projekcyjnych jako narzędzi diagnozy psychologicznej. Część 1: Czemu niektóre techniki niesłusznie nazywa się projekcyjnymi?. Psychologia kliniczna, 2013; (94): 421-520.

19. Lilienfeld OS, Wood MJ, Garb NH. Status Naukowy technik projekcyjnych. Kraków: Wydawnictwo Uniwersytetu Jagiellońskiego, 2002.

20. Hornowska E. Testy psychologiczne - teoria i praktyka. Warszawa: Wydawnictwo Naukowe Scholar, 2001.

\section{Correspondence address:}

Aleksandra Iwanicka,

II Klinika Psychiatrii i Rehabilitacji Psychiatrycznej w Lublinie iwanicka.aleksandra123@gmail.com

Otrzymano: 28.09.2018

Zrecenzowano: 22.10.2018

Przyjęto do druku: 13.11.2018 